\section{Influences of Black Locust (Robinia pseudoacacia L.) afforestation on soil microbial biomass and activity}

\author{
Ilyas Bolat ${ }^{(1)}$, Ömer Kara ${ }^{(2)}$, Hüseyin Sensoy ${ }^{(3)}$, Kivanç Yüksel ${ }^{(4)}$
}

Black locust is a tree species considered suitable for afforestation in Turkey because of its rapid growth and ability to fix atmospheric nitrogen in disturbed soil ecosystems. Quantitative indicators of soil health and quality can be usefully derived from a data set of soil physical, chemical and microbial characteristics. In this study changes in soil characteristics after afforestation with black locust were assessed by comparing several afforestation sites with control (no vegetation) sites randomly chosen along the roadside in Ulus-Bartin, the western Black Sea region (Turkey). Results showed that some physical and chemical characteristics of the soil (soil bulk density, clay content, soil organic $\mathrm{C}$ and total $\mathrm{N}$ ) were higher at the afforestation sites as compared with the control sites. Similarly, afforestation sites showed higher values for mean soil microbial biomass C (afforestation: $311.97 \mu \mathrm{g} \mathrm{g}^{-1}$; control: $149.68 \mu \mathrm{g} \mathrm{g}^{-1}$ ) and $\mathrm{N}$ (afforestation: $43.07 \mu \mathrm{g} \mathrm{g}^{-1}$; control: $19.21 \mu \mathrm{g} \mathrm{g}^{-1}$ ), and basal respiration (afforestation: $0.303 \mu \mathrm{g} \mathrm{CO}-\mathrm{C} \mathrm{g} \mathrm{g}^{-1} \mathrm{~h}^{-1}$; control: $0.167 \mu \mathrm{CO}_{2}-\mathrm{C} \mathrm{g}^{-1} \mathrm{~h}^{-1}$ ). However, the mean metabolic quotient $\left(\mathrm{qCO}_{2}\right)$ assessed at the control sites was higher $\left(1.47 \mathrm{mg} \mathrm{CO}_{2}-\mathrm{C} \mathrm{g}^{-1} \mathrm{C}_{\text {mic }} \mathrm{h}^{-1}\right)$ than that observed the afforestation sites $(0.96 \mathrm{mg}$ $\left.\mathrm{CO}_{2}-\mathrm{C} \mathrm{g}^{-1} \mathrm{C}_{\text {mic }} \mathrm{h}^{-1}\right)$, likely due to difficulties in the utilization of organic substrates by the microbial community. In addition, the correlation between the $\mathrm{qCO}_{2}$ and $C_{\text {mic }} / C_{\text {org }}$ percentages was negative $(r=-0.586, P<0.01)$ in both sites. Our results indicated that afforestation with black locust could be advantageous, not only for soil improvement and regeneration, but also for sustainable land management.

Keywords: Basal Respiration, $C_{\text {mic }} / C_{\text {org }}$ Percentage, $C_{\text {mic }} / N_{\text {mic }}$ Ratio, Metabolic Quotient $\left(\mathrm{qCO}_{2}\right)$, Nitrogen Fixation

\section{Introduction}

Soil health and quality may be successfully monitored through the use of two microbial indexes: (i) the microbial biomass, which is defined by the living component of soil organic matter, excluding the macrofauna and plant roots; and (ii) soil microbial respiration (basal respiration), which is described by the respiration without the addition of an organic substrate to soil (Jenkinson \& Ladd 1981, Alef 1995, Sparling 1997). The microbial biomass is small and labile as compared with other ecosystem components; however, because of its key role in the mineralization of nutrients such as $\mathrm{C}, \mathrm{N}, \mathrm{P}$ and $\mathrm{S}$, it is considered a reliable indicator of changes in soil characteristics (Jenkinson \& Ladd 1981, Powlson et al. 1987, Balota et al. 2003). Balota et al. (2013) report that changes in the microbial properties of soil may lead to important changes in soil quality, thus affecting nutrient cycling and plant development. Haris (2003) clearly affirmed that the microbial community serves as an indicator

$\square$ (1) Bartin University, Faculty of Forestry, Department of Forest Engineering, Division of Soil Science and Ecology, Bartin (Turkey); (2) Karadeniz Technical University, Faculty of Forestry, Department of Forest Engineering, Division of Watershed Management, Trabzon (Turkey); (3) Bartin University, Faculty of Forestry, Department of Forest Engineering, Division of Watershed Management, Bartin (Turkey); (4) Kahramanmaras Sutcu Imam University, Faculty of Forestry, Department of Forest Engineering, Kahramanmaras (Turkey)

@) Ilyas Bolat (ilyasbolat@bartin.edu.tr)

Received: Jul 27, 2014 - Accepted: Oct 16, 2014

Citation: Bolat I, Kara Ö, Sensoy H, Yüksel K, 2016. Influences of Black Locust (Robinia pseudoacacia L.) afforestation on soil microbial biomass and activity. iForest 9: 171-177 [online 2015-02-16] URL: http://www.sisef.it/iforest/contents/?id=ifor1410-007

Communicated by: Gianfranco Minotta

of the re-establishment of connections between ecological functions of the biota in disturbed ecosystems. Despite the large variations in mineralogy, soil texture and land use type, extreme environments usually show low organic matter and very low microbial biomass contents, which indicate poor soil quality and limited site productivity (Sparling 1997, Guénon et al. 2013).

Soil basal respiration is a well-established parameter to be measured through the decomposition process, and it is defined as the overall activity or energy spent by the indigenous microbial pool (Anderson \& Domsch 1990, Sparling 1997). Insam et al. (1991) argued that soil basal respiration reflects the availability of slow-flowing $\mathrm{C}$ for microbial permanence and is a measure of basic turnover rates in soil.

Robinia pesudoacacia L. (black locust or false acacia) is a deciduous, broad-leaved, light-demanding, medium-sized pioneer tree ranging in height $20-25 \mathrm{~m}$. Black locust is regarded as an invasive, non-indigenous species in many parts of Europe, such as Germany, Italy and Turkey (Ansin \& Özkan 1997, Cierjacks et al. 2013). It is well-adapted to grow on different types of soil and environmetal conditions, though it avoids compacted or wet soils. Indeed, its demand for aerated soil is the reason why black locust can be primarily found in disturbed sites from poor to fertile soils (Sabo 2000, Cierjacks et al. 2013). Black locust shows a rapid growth and adaptability, for it has been utilized for soil conservation or fuel wood, as well as for early reforestation of barren soils at disturbed sites (Landgraf et al. 2005, Keskin \& Makineci 2009, Noh et al. 2010). However, in Turkey it has been long cultivated as an ornamental plant and it can be currently found in schoolyards, roadsides or other marginal lands (Ansin \& Özkan 1997). This tree species is characterized by an extensive root system (Zhou \& Shangguan 2005) nodulated by diverse nitrogen-fixing Rhizobium communities, providing the host with an advantage over native species on poor soils, and increasing thoroughly the soil nitrogen content (Noh et al. 2010, Qiu et al. 2010, Cierjacks et al. 2013). For these reasons, black locust is presumed to be a favorable tree species for soil reclamation and regeneration of disturbed sites, such as roadsides and former mine sites.

Although many studies has been conducted on the influences of black locust on soil physicochemical and nutritional properties (Danso et al. 1995, Tateno et al. 2007, Wang et al. 2012, Zhao et al. 2013), the reclamation of soil properties by black locust is still not well understood (Keskin \& Makineci 2009, Yüksek 2012), especially in terms of microbial biomass and activity.

The purpose of the study was to investigate 


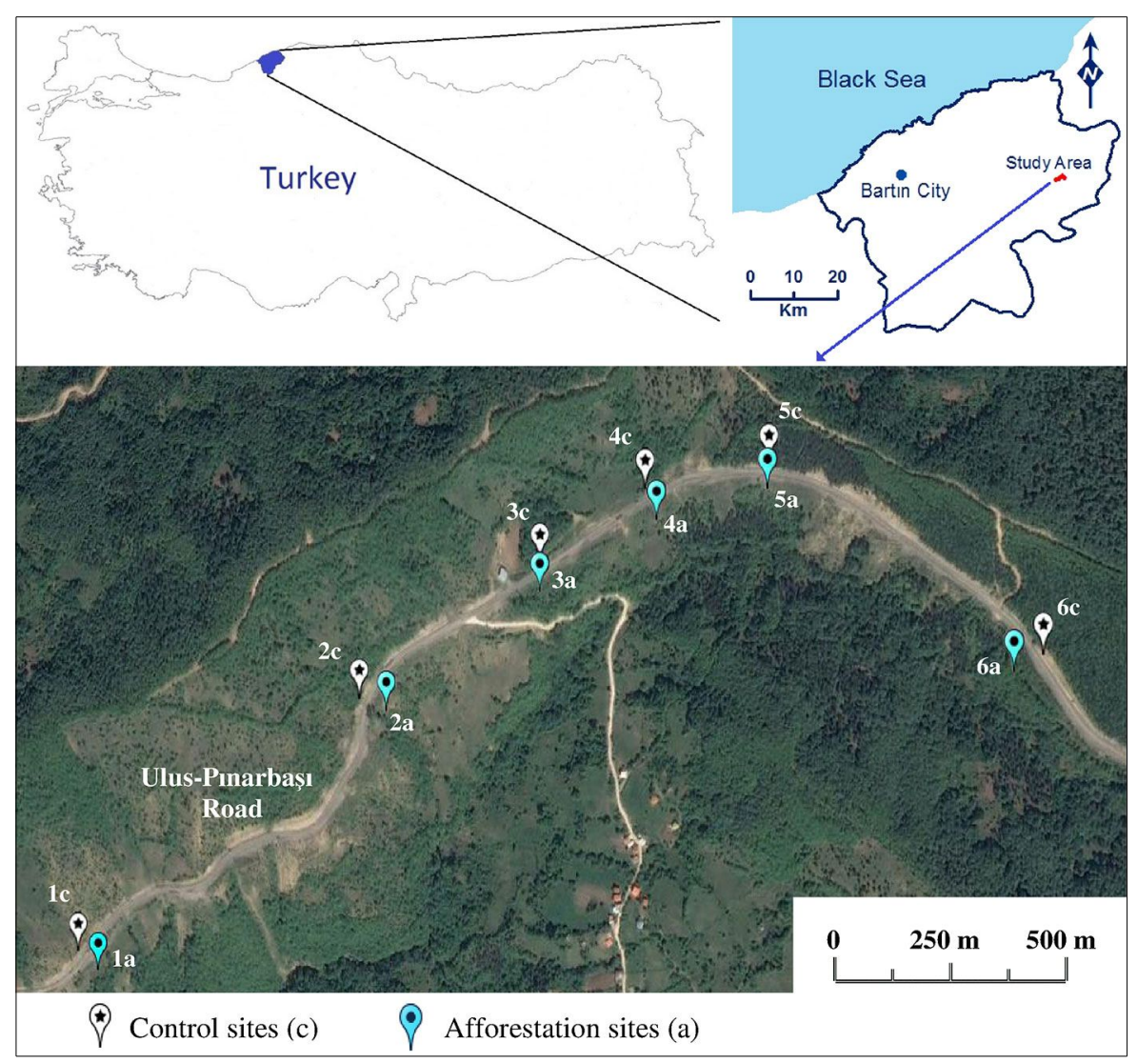

Fig. 1 - Sampling sites in the study area (Ulus-Pinarbasi road, Ulus-Bartin, western Black Sea region, Turkey).

the effect of afforestation with black locust on: (1) soil physical and chemical properties, such as soil moisture, bulk density, soil organic $\mathrm{C}$ and total $\mathrm{N}$ content; (2) soil microbial biomass $\mathrm{C}\left(\mathrm{C}_{\text {mic }}\right)$ and $\mathrm{N}\left(\mathrm{N}_{\text {mic }}\right)$; and (3) soil microbial activity as basal respiration.

\section{Materials and methods}

\section{Site description}

The study was conducted at a black locust 8 -years-old afforestation site located in Ulus-Bartin, the western Black Sea region of Turkey $\left(32^{\circ} 45^{\prime} 47^{\prime \prime}-32^{\circ} 47^{\prime} 06^{\prime \prime} \mathrm{E}, 41^{\circ} 37^{\prime}\right.$ $\left.34^{\prime \prime}-41^{\circ} 38^{\prime} 02^{\prime \prime} \mathrm{N}\right)$. Based on the Thornthwaite method (Thornthwaite 1948), the study site has a humid, mesothermal oceanic-like climate, with little or none water summer deficit. According to climatological data over the past 30 years (TSMS 2013), the average annual air temperature is $9.1^{\circ} \mathrm{C}$, the average temperature of the coldest month (January) is $3.0^{\circ} \mathrm{C}$, and the average temperature of the warmest month (July) is $16.2^{\circ} \mathrm{C}$. Average annual precipitation is $1385.1 \mathrm{~mm}$, with about $35 \%$ of rainfall occurring from May to September. Relative humidity is nearly $80 \%$. The main bedrock of the study site is calcareous limestone, with a stony and coarse texture.

Two-years-old seedlings of black locust were planted in 2008 along the roadsides of the Ulus-Pinarbasi road. The study was carried out in July 2013, when the black locust trees were eight years old. Tree diameter at breast height ranged from 10 to $18 \mathrm{~cm}$, while tree height varied between 5 and $8 \mathrm{~m}$. As a control site (with no afforestation), an area located on the opposite side of the road and lacking in any tree species and vegetation was selected. Mean elevation at the study site was $775 \mathrm{~m}$ a.s.1., ranging between 650 and $900 \mathrm{~m}$, with a south-southeast aspect and a slope of $40-50 \%$.

Six sampling locations (named 1 to 6 ) were established along the roadsides (Fig. 1), with a distance of $2.2 \mathrm{~km}$ between the farthest locations ( 1 and 6). The distance between points 1 and 2 was $750 \mathrm{~m} ; 2-3: 400 \mathrm{~m} ; 3-4$ : $250 \mathrm{~m} ; 4-5: 250 \mathrm{~m} ; 5-6: 550 \mathrm{~m}$. At each location, soil sampling was carried out on both sides of the road: the control, vegetation-free points ( $1 \mathrm{c}$ to $6 \mathrm{c})$ on one side, and the afforested points (1a to 6a) on the opposite side. The distance from the road of both the control (c) and the afforestation points (a) was approximately $4-5 \mathrm{~m}$.

\section{Soil sampling}

To determine physical and chemical properties of the soil, samples of topsoil (0-6.5 $\mathrm{cm}$ depth, $8.1 \mathrm{~cm}$ in diameter) were random- ly collected at both control and afforestation points, totaling 12 sampling points. The same number of samples were also taken from topsoil at the same locations for microbial analysis after removing stones, plant and root debris. A soil depth of $0-6.5 \mathrm{~cm}$ was chosen for sampling, since this layer was considered to be more susceptible to any change (e.g., afforestation) as compared with lower layers.

Soil samples for microbial analysis were sifted with 2 -mm sieves and stored at $4{ }^{\circ} \mathrm{C}$ until the measurement of the microbial biomass $\mathrm{C}$ and $\mathrm{N}$, and basal respiration. Instead, soil cores for physical and chemical analysis were air-dried, ground and sieved $(<$ $2 \mathrm{~mm}$ ).

\section{Physical and chemical analyses}

The moisture content of soil samples was determined gravimetrically by oven-drying at $105{ }^{\circ} \mathrm{C}$ until a constant weight was reached. The hydrometer method was used to calculate the particle size distribution of the soil (Bouyoucos 1962). Soil pH was measured in a 1:2.5 soil:water suspension using a $\mathrm{pH}$ meter, while the electrical conductivity of the soil was determined on a 1:5 soil:water extract with an electrical conductivity meter. Organic $\mathrm{C}$ content of soil samples was estimated using potassium dichromate oxidation, and the total $\mathrm{N}$ content was determined by Kjeldahl digestion. The Scheibler calcimeter method was used to measure the $\mathrm{CaCO}_{3}$ content of the soil (Rowell 1994). Soil bulk density $\left(\mathrm{g} \mathrm{cm}^{-3}\right)$ was calculated using mass and volume (Blake \& Hartge 1986). The particle density of the soils (g $\mathrm{cm}^{-3}$ ) was measured using the Pycnometer method and pore space was calculated using bulk and particle densities (Brady 1990).

\section{Biochemical analyses}

Microbial biomass $\mathrm{C}$ and $\mathrm{N}$ were determined by the chloroform fumigation extraction method (Anderson \& Ingram 1996). Microbial biomass $\mathrm{C}\left(C_{\text {mic }}\right)$ was determined by a modified Walkley-Black method (Brookes et al. 1985, Vance et al. 1987) using the following equation (Vance et al. 1987 - eqn. 1):

$$
C=K_{E C} \cdot 2.64
$$

where $K_{\mathrm{EC}}$ refers to the difference in extractable organic $\mathrm{C}$ between the fumigated and unfumigated samples, and 2.64 is a proportionality factor used for the biomass $C$ released by fumigation extraction.

The method described by Brookes et al. (1985) and Anderson \& Ingram (1996) was used for measuring the microbial biomass $\mathrm{N}$ $\left(N_{\text {mic }}\right)$, calculated as follows (eqn. 2$)$ :

$$
N=\frac{F_{N}}{0.54}
$$

where $F_{\mathrm{N}}$ is the difference between $N$ ex- 
tracted from fumigated and unfumigated samples. The fraction of microbial biomass $N$ released by fumigation extraction is 0.54 .

Basal respiration was determined by the sodium hydroxide $(\mathrm{NaOH})$ trap method (Alef 1995). The metabolic quotient $\left(\mathrm{qCO}_{2}\right)$ was calculated as the basal respiration rate (mg CO$\left.{ }_{2}-\mathrm{C} \mathrm{h}^{-1}\right) \mathrm{g}^{-1}$ of microbial biomass (Anderson \& Domsch 1990)

All the above analyses were performed with two replications, and the data obtained were averaged over replicates and expressed on an oven-dry weight basis.

\section{Statistical analyses}

Differences in microbial biomass $\mathrm{C}$ and $\mathrm{N}$, basal respiration and the physical and chemical characteristics of the soil between control and afforestation sites were tested through independent samples $t$-tests $(\alpha=0.05)$. Correlation analysis was applied to assess the relationships between microbial biomass $\mathrm{C}$ with basal respiration, and $C_{\text {mid }} / C_{\text {org }}$ with $\mathrm{qCO}_{2}$. All the analyses were carried out using the statistical package SPSS ${ }^{\circledR}$ ver. 16.0

\section{Results and discussion}

The results of the comparison of the control and afforestation sites in terms of physical and chemical characteristics of soil are summarized in Tab. 1. No differences ( $\mathrm{P}>$ 0.05 ) were found for soil particle density, sand fraction, silt fraction and calcium carbonate content. Soil bulk density was considerably higher $(\mathrm{P}<0.05)$ in the afforestation site as compared with the control site. Conversely, soil pore space was significantly higher $(\mathrm{P}<0.05)$ in the control site than in the afforestation site. It is implied in the literature that any factor influencing soil pore space will also affect bulk density. Obviously, since bulk density relates to the combined volumes of the solids and pore spaces, soils with a high proportion of pore space to solids have also lower bulk densities (Brady 1990). In both control and afforestation sites, the soil was sandy clay loam with 49.29 $51.42 \%$ sand, $17.55-21.33 \%$ silt and 27.25 $33.16 \%$ clay. The soil at the afforestation site had a relatively higher percentage of soil moisture than the soil at the control site, likely due to the higher clay content and the presence of vegetation in the afforestation site. Such results support the evidence that soil texture (especially clay content) and vegetation are important factors in determining the proportion of soil moisture (English et al. 2005, Kara \& Bolat 2008).

The $\mathrm{pH}$ of soil in the control site was significantly higher than that of soil in the afforestation site (Tab. 1). Soils at both sites were also medium alkaline, which could be due to calcareous limestone. An obvious difference in soil electrical conductivity (EC) between the studied sites was observed. However, the soils analyzed cannot be clas-
Tab. 1 - Comparisons of the physical and chemical characteristics of the soil at the control and afforestation sites $(0-6.5 \mathrm{~cm}$ depth). Values within rows followed by the different letters indicate a significant difference between the control and afforestation sites after independent sample $t$-test $(\mathrm{P}<0.05)$. Values represent the mean of 12 samples \pm standard error.

\begin{tabular}{lcc}
\hline Soil characteristics & Control site & Afforestation site \\
\hline Bulk density $\left(\mathrm{g} \mathrm{cm}^{-3}\right)$ & $1.54 \pm 0.048^{\mathrm{a}}$ & $1.71 \pm 0.056^{\mathrm{b}}$ \\
Particle density $\left(\mathrm{g} \mathrm{cm}^{-3}\right)$ & $2.77 \pm 0.01^{\mathrm{a}}$ & $2.77 \pm 0.02^{\mathrm{a}}$ \\
Pore space $(\%)$ & $44.58 \pm 1.70^{\mathrm{a}}$ & $38.12 \pm 2.21^{\mathrm{b}}$ \\
Sand $(\%)$ & $51.42 \pm 3.53^{\mathrm{a}}$ & $49.29 \pm 2.46^{\mathrm{a}}$ \\
$\mathrm{Silt}(\%)$ & $21.33 \pm 2.97^{\mathrm{a}}$ & $17.55 \pm 0.88^{\mathrm{a}}$ \\
Clay $(\%)$ & $27.25 \pm 1.04^{\mathrm{a}}$ & $33.16 \pm 1.91^{\mathrm{b}}$ \\
Soil texture & Sandy clay loam & Sand clay loam \\
Moisture content $(\%)$ & $9.63 \pm 0.46^{\mathrm{a}}$ & $11.44 \pm 0.50^{\mathrm{b}}$ \\
Soil pH $\left(\mathrm{H}_{2} \mathrm{O}\right)$ & $8.43 \pm 0.02^{\mathrm{a}}$ & $8.26 \pm 0.04^{\mathrm{b}}$ \\
Calcium carbonate $\left(\mathrm{CaCO}_{3}-\%\right)$ & $7.52 \pm 0.68^{\mathrm{a}}$ & $7.71 \pm 0.59^{\mathrm{a}}$ \\
Electrical conductivity $\left(\mathrm{dS} \mathrm{m}^{-1}\right)$ & $0.92 \pm 0.03^{\mathrm{a}}$ & $1.11 \pm 0.03^{\mathrm{b}}$ \\
Organic C $(\%)$ & $0.45 \pm 0.03^{\mathrm{a}}$ & $0.64 \pm 0.04^{\mathrm{b}}$ \\
Total N $(\%)$ & $0.14 \pm 0.003^{\mathrm{a}}$ & $0.17 \pm 0.008^{\mathrm{b}}$ \\
$\mathrm{C}_{\text {org }} / \mathrm{N}_{\text {total }}$ ratio & $3.16 \pm 0.24^{\mathrm{a}}$ & $3.92 \pm 0.25^{\mathrm{b}}$ \\
\hline
\end{tabular}

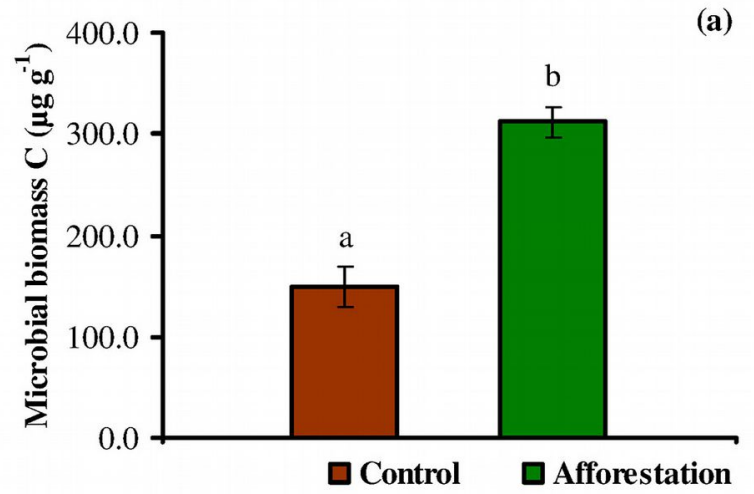

Fig. 2 - Changes in mean soil microbial biomass $\mathrm{C}(\mathrm{a})$, soil microbial biomass $\mathrm{N}(\mathrm{b})$ and soil basal respiration (c) in the soil at the control and afforestation sites (errors bars represent standard error). Significant differences $(P<0.05)$ between the control and afforestation sites are indicated by different letters $(\mathrm{a}, \mathrm{b})$ after independent sample $t$-test $(\mathrm{P}<$ $0.05)$.
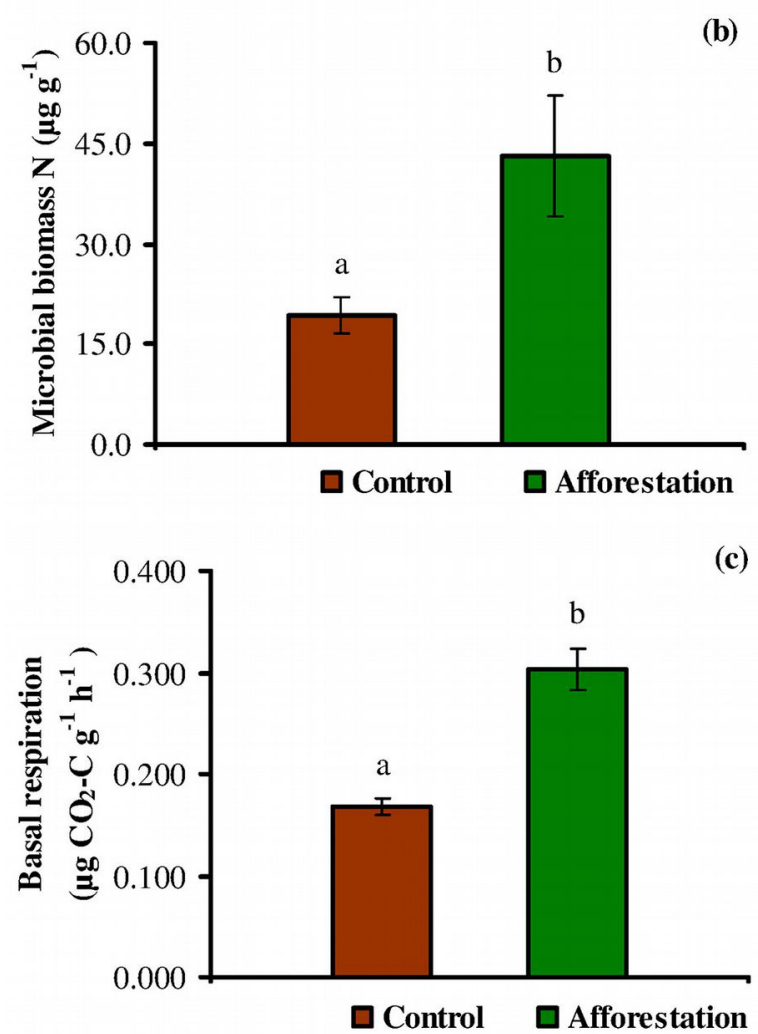
Fig. 3 - The relation between the microbial biomass $\mathrm{C}$ and basal respiration (a), $C_{\text {mic }} / C_{\text {org }}$ and $\mathrm{qCO}_{2}$ (b) for soils sampled at the control and afforestation sites.

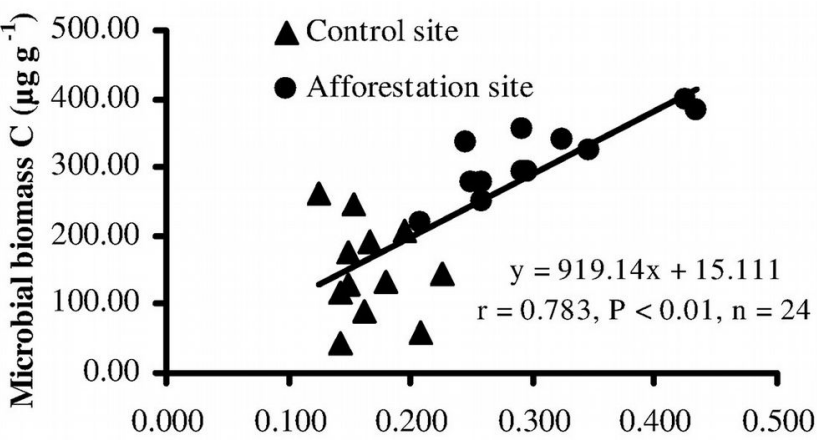

(a)

Basal respiration $\left(\mu \mathrm{g} \mathrm{CO} \mathrm{CO}_{2}-\mathrm{C} \mathrm{g}^{-1} \mathrm{~h}^{-1}\right)$

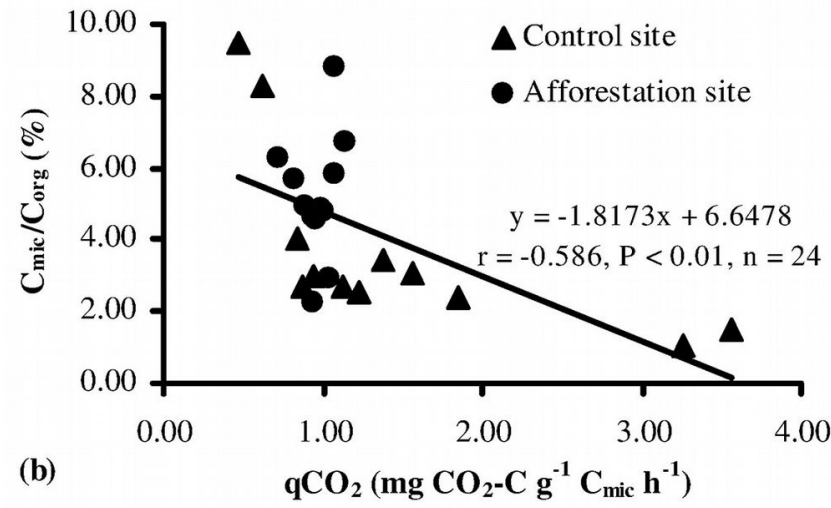

sified as saline, since they did not show an $\mathrm{EC}$ of $4 \mathrm{dS} \mathrm{m}^{-1}$ or more (Sumner 1995). Soil organic $\mathrm{C}$ and total $\mathrm{N}$ are important factors that contribute to improve the physical properties of soil, and then its productivity. The largest soil organic $\mathrm{C}$ and total $\mathrm{N}$ amount were detected in the soils sampled at the afforestation sites. Such evidence is reasonably related to their higher clay content (Campbell et al. 1996), the presence and diversity of tree species (Oostra et al. 2006, Tateno et al. 2007, Kara \& Bolat 2008), the higher input of root exudates and plant residues (García-Orenes et al. 2010), and the chemical composition of litter (Johansson 1995). Moreover, the above evidence suggest that the observed improvement of the soil is the result of the afforestation with the black locust, which appears to be primarily responsible for the increase in soil organic C and total $\mathrm{N}$, according to previous reports by Rice et al. (2004), Keskin \& Makineci (2009) and Yüksek (2012). We hypothesized that the low

$C_{\text {org }} / N_{\text {total }}$ ratio observed at the control sites $(3.16 \pm 0.24)$ may be due to the rapid breakdown of nitrogen-containing compounds and intensive carbon mineralization, i.e., the higher degree of decomposition of the organic matter (Zeller et al. 2000, Diekow et al. 2005). On the other hand, the high $C_{\text {org }} / N_{\text {total }}$ ratio found in soils from afforested sites can be explained by higher inputs of soil organic carbon, as revealed by the significantly higher soil organic $\mathrm{C}$ content in the afforestation sites compared with the control sites (Tab. 1). Moreover, it has been reported in the literature that when organic residues with a high $\mathrm{C}_{\text {org }} / \mathrm{N}_{\text {total }}$ ratio are added to the soil, a keen competition arises among microorganisms for available soil nitrogen, leaving less nitrogen available for nitrification (Brady 1990, Lovett et al. 2002).

The mean soil microbial biomass $\mathrm{C}\left(C_{\text {mic }}\right)$ was nearly $48 \%$ higher in the afforestation sites than the control sites (Fig. 2a). At the control sites, $C_{\text {mic }}$ values ranged from 43.89

Tab. 2 - Derived microbial indexes calculated for control and afforestation sites $(0-6.5 \mathrm{~cm}$ depth). Values within rows row followed by the same letter indicate no significant difference between the means (independent sample $t$-test $-\mathrm{P}>0.05$ ). Values represent the mean of 12 samples \pm standard error.

\begin{tabular}{lcc}
\hline Microbial index & Control sites & Afforestation sites \\
\hline$C_{\text {mic }} / C_{\text {org }}(\%)$ & $3.67 \pm 0.74^{\mathrm{a}}$ & $5.17 \pm 0.49^{\mathrm{a}}$ \\
$C_{\text {mic }} / N_{\text {mic }}(\%)$ & $8.40 \pm 1.05^{\mathrm{a}}$ & $10.83 \pm 1.73^{\mathrm{a}}$ \\
$N_{\text {mic }} / N_{\text {total }}(\%)$ & $1.38 \pm 0.21^{\mathrm{a}}$ & $2.95 \pm 0.72^{\mathrm{a}}$ \\
$\mathrm{qCO}_{2}\left(\mathrm{mg} \mathrm{CO}_{2}-\mathrm{C} \mathrm{g}^{-1} C_{\text {mic }} \mathrm{h}^{-1}\right)$ & $1.47 \pm 0.28^{\text {a }}$ & $0.96 \pm 0.03^{\text {a }}$ \\
\hline
\end{tabular}

to $261.95 \mu \mathrm{g} \mathrm{g}^{-1}$, while the corresponding range for the afforestation sites was 219.42$397.11 \mu \mathrm{g} \mathrm{g}^{-1}$. Similarly, the mean soil microbial biomass $\mathrm{N}\left(N_{\text {mic }}\right)$ was approximately $45 \%$ higher in the afforestation sites than in the control sites (Fig. 2b), varying from 10.41 to $42.83 \mu \mathrm{g} \mathrm{g}^{-1}$ and from 11.74 to $98.37 \mu \mathrm{g} \mathrm{g}^{-1}$ in the control and the afforestation sites, respectively. Hence, the afforestation sites have a higher microbial biomass $\mathrm{C}$ and $\mathrm{N}$, and the presence of black locust trees has a significant $(\mathrm{P}<0.05)$ effect on soil $C_{\text {mic }}$ and $N_{\text {mic }}$ (Fig. 2a, Fig. 2b). According to McGill et al. (1986), an increase in soil microbial biomass could result in the immobilization of soil nutrients, whereas its decrease may lead to nutrient mineralization. Also, it has been suggested that a low microbial biomass in the soil could be a hint of either stress or disturbance (Wardle 1993). According to previous studies (Vitousek \& Walker 1989, Pereira et al. 2011, Fterich et al. 2014), our findings confirm that the nitrogen-fixing black locust tree may contribute to the soil $C_{\text {mic }}$ and $N_{\text {mic }}$ pools, improving the rates of carbon and nitrogen cycling and their availability. Moreover, previous studies reported that black locust could be largely ameliorative by promoting the amount and availability of $\mathrm{N}$ in the soil (Tateno et al. 2007, Qiu et al. 2010, Yüksek 2012), improving the quality and structure of soil, and increasing root biomass and soil organic $\mathrm{C}$ sequestration (Ussiri et al. 2006, Yüksek 2012), thus ameliorating the biological properties of soils (Xue et al. 2007, Wang et al. 2012). Furthermore, some authors argued that the microbial dynamic pool is attached to the organic residues that supply available $\mathrm{C}$ and nitrogen contents in the soil (Wardle 1992, Araujo et al. 2010).

Soil basal respiration provides an estimate of the microbial activity, being a proxy of the cycling of organic carbon and organic carbon-bound nutrients $(\mathrm{N}, \mathrm{S}, \mathrm{P})$ within an ecosystem (Winding et al. 2005). In this stu$\mathrm{dy}$, basal respiration rates of the soil ranged from 0.125 to $0.227 \mu \mathrm{g} \mathrm{CO}_{2}-\mathrm{C} \mathrm{g}^{-1} \mathrm{~h}^{-1}$ at the control sites and from 0.208 to $0.435 \mu \mathrm{g}$ $\mathrm{CO}_{2}-\mathrm{C} \mathrm{g}^{-1} \mathrm{~h}^{-1}$ at the afforestation sites, the latter showing values significantly higher than control sites $(\mathrm{P}<0.05$ - Fig. $2 \mathrm{c})$. Also, basal respiration demonstrated a significant positive correlation with microbial biomass $\mathrm{C}$ (Fig. 3a). The high basal respiration rate observed in the soil at the afforestation sites might be due to the high moisture content, organic carbon, microbial biomass, and tree root biomass. Indeed, basal respiration is a well-established parameter to monitor decomposition (Alef 1995, Sparling 1997, Winding et al. 2005), although it is often affected by wide natural fluctuations, depending on soil moisture, substrate availability and soil temperature. Nsabimana et al. (2004) and Cheng \& Xia (2012) asserted 
that soil basal respiration was positively correlated with soil organic carbon and microbial biomass, and the availability of suitable substrates (protein, carbohydrate, glucose, etc.) is the main factor influencing the activity of microbial community. Islam \& Weil (2000) and Campos et al. (2012) argued that high rates of basal respiration can occur either as a result of a large pool of labile $C$ substrates or rapid oxidation of a smalle pool. Thus, high basal respiration may indicate either ecological stress and degradation or a high level of ecosystem productivity. For the above reasons, a more clearly interpretable parameter is the rate of basal respiration per unit of microbial biomass $\left(\mathrm{qCO}_{2}\right.$ see below).

In this study, the ratio $C_{\text {mic }} / C_{\text {org }}$ was higher in the afforestation sites as compared with the control sites, though such difference was not statistically significant $(\mathrm{P}>0.05-\mathrm{Tab}$ $2)$. About $2.2 \%$ of soil organic carbon is constituted of microbial biomass, a value above the equilibrium threshold proposed by Jenkinson \& Ladd (1981), though the observed variation $(0.27-7.0 \%)$ was well within the range suggested by Anderson \& Domsch (1989). According to these authors, the $C_{\text {mic }} / C_{\text {org }}$ ratio may be considered a suitable indicator of the soil carbon dynamics, and its variation is regarded as a hint of environmental changes in the soil (Bauhus et al 1998, Anderson 2003, Ferreira et al. 2014). In this study, the high $C_{\text {mid }} / C_{\text {org }}$ ratio found at the afforestation sites suggests suitable environmental conditions for the proliferation of soil microrganisms.

Similarly, the ratio $C_{\text {mic }} / N_{\text {mic }}$ observed at the afforestation sites was higher than that found at the control sites, though not significantly different ( $\mathrm{P}>0.05$ - Tab. 2). The $C_{\text {mic }} / N_{\text {mic }}$ ratio is frequently used to define the structure of the microbial community: it has been pointed out that a high $C_{\text {mic }} / N_{\text {mic }}$ ratio (range: 7-12) may indicate a predominance of fungi in the soil microbial biomass, whereas a low $C_{\text {mid }} / N_{\text {mic }}$ ratio (range: $3-6$ ) may indicate a predominant proportion of bacteria in the microbial community (Jenkinson 1988). According to the above considerations, fungi may represent the dominant populations in the soil at the studied sites.

The $N_{\text {mid }} / N_{\text {total }}$ ratio exhibited the same pattern observed for $C_{\text {mid }} / C_{\text {org }}$ and $C_{\text {mid }} / N_{\text {mic }}$ (Tab. $2)$. Based on the scientific literature, a relatively high $N_{\text {mic }} / N_{\text {total }}$ value indicates that the availability of organic nitrogen components is not a limiting factor for microbial biomass (Khan \& Joergensen 2006), whereas a low $N_{\text {mid }} / N_{\text {total }}$ indicates a decline in substrate quality (Bauhus et al. 1998).

The metabolic quotient $\left(\mathrm{qCO}_{2}\right)$ is defined as the substrate mineralized per unit of microbial biomass carbon (Bastida et al. 2008), and it has been extensively used to evaluate ecosystem development, disturbance, or sys- tem maturity. Anderson \& Domsch (1986) and Bauhus \& Khanna (1999) reported that a high $\mathrm{qCO}_{2}$ value may be a hint of low available $\mathrm{C}$ content and substrate quality for microbial biomass, thereby less biomass could be produced since more carbon is used for respiration, thus reflecting a poor rhizosphere health (Anderson 2003, Ferreira et al. 2014, Fterich et al. 2014). In this study, $\mathrm{qCO}_{2}$ in the control sites was higher (though not significantly) than that observed at the afforestation sites (Tab. 2). Such results may be due to difficulties in the utilization of organic substrates by the microbial community at the control sites, and/or to unsuitable soil conditions. Additionally, a close negative relationship between $\mathrm{qCO}_{2}$ and the $C_{\text {mid }} / C_{\text {org }}$ ratio was found (Fig. 3b), according to previous studies (Bauhus \& Khanna 1999, Kara et al. 2010, Bolat 2014). Furthermore, several authors have argued that a low $\mathrm{qCO}_{2}$ and a high $C_{\text {mic }} / C_{\text {org }}$ ratio (Tab. 2) may indicate a more efficient use of organic substrates by microbial biomass (Anderson 2003) and higher microbial activity (Liao \& Boutton 2008).

\section{Conclusions}

In this study, soil chemical characteristics, soil microbial biomass and activity were compared between control and afforestation sites sampled at 12 locations along the UlusPinarbasi road (western Black Sea region, Turkey). The results showed that black locust trees used in the afforestation has positively affected both soil microbial biomass and activity, improving soil characteristics and promoting its quality and health. Despite the invasive nature of black locust, this species could be preferred in such disturbed sites because of its rapid growth, soil amelioration and resistance to harsh environmental conditions. The results of this study may be considered as a baseline for monitoring the possible future changes in the microbial biomass and activity of soil in black locust afforestation sites.

\section{Acknowledgements}

We acknowledge the Ulus Forest Administration and Turkish State Meteorological Service (TSMS) for their assistance and data support throughout the study. We would like to thank two anonymous referees for their helpful comments and suggestions.

\section{References}

Alef K (1995). Soil respiration. In: "Methods in applied soil microbiology and biochemistry" (Alef P, Nannipieri K eds). Academic Press, London, UK, pp. 214-218.

Anderson TH, Domsch KH (1986). Carbon link between microbial biomass and soil organic matter. In: "Perspectives in microbial ecology" (Megusar F, Gantar M eds). Slovene Society for Microbiology, Ljubljana, Mladinska knjiga, pp.
467-471.

Anderson JPE, Domsch KH (1989). Ratios of microbial biomass carbon to total organic carbon in arable soils. Soil Biology and Biochemistry 21: 471-479. - doi: 10.1016/0038-0717(89)90117-X Anderson TH, Domsch KH (1990). Application of eco-physiological quotients (qCO2, and $\mathrm{qD})$ on microbial biomasses from soils of different cropping histories. Soil Biology and Biochemistry 22: 251-255. - doi: 10.1016/0038-0717(90)900 94-G

Anderson JM, Ingram JSI (1996). Tropical soil biology and fertility: a handbook of methods $\left(2^{\text {nd }}\right.$ edn). CAB International, Wallingford, UK, pp. 68-70.

Anderson TH (2003). Microbial eco-physiological indicators to assess soil quality. Agriculture Ecosystems and Environment 98: 285-293. - doi: 10.1016/S0167-8809(03)00088-4

Ansin R, Özkan ZC (1997). Seed plants (Spermatophyta): woody taxons. Karadeniz Technical University Publication No. 167, Forest Faculty Publication No. 19, Trabzon, Turkey, pp. 449452. [in Turkish]

Araujo ASF, Silva EFL, Nunes LAPL, Carneiro RFV (2010). The effect of converting tropical native savanna to Eucalyptus grandis forest on soil microbial biomass. Land Degradation and Development 21 (6): 540-545. - doi: 10.1002/ 1dr.993

Balota EL, Colozzi-Filho A, Andrade DS, Dick RP (2003). Microbial biomass in soils under different tillage and crop rotation systems. Biology and Fertility of Soils 38: 15-20. - doi: 10.1007/ s00374-003-0590-9

Balota EL, Yada IF, Amaral H, Nakatani AS, Dick RP, Coyne MS (2013). Long- term land use influences soil microbial biomass $\mathrm{P}$ and $\mathrm{S}$, phosphatase and arylsulfatase activities, and $\mathrm{S}$ mineralization in a Brazilian oxisol. Land Degradation and Development. - doi: 10.1002/ldr.2242

Bastida F, Zsolnay A, Hernández T, García C (2008). Past, present and future of soil quality indices: a biological perspective. Geoderma 147 (3): 159-171. - doi: 10.1016/j.geoderma.2008. 08.007

Bauhus JD, Pare D, Cote L (1998). Effects of tree species, stand age, and soil type on soil microbial biomass and its activity in a southern boreal forest. Soil Biology and Biochemistry 30: 1077 1089. - doi: 10.1016/S0038-0717(97)00213-7

Bauhus J, Khanna PK (1999). The significance of microbial biomass in forest soils. In: "Going underground-ecological studies in forest soils" (Rastin N, Bauhus J eds). Research Signpost, Trivandrum, India, pp. 77-110. [online] URL: http://www.cabdirect.org/abstracts/20001906347 .html

Blake GR, Hartge KH (1986). Bulk density. In: "Methods of Soil Analysis, Part 1. Physical and Mineralogical Methods" (Klute A ed). Agronomy Monograph 9, American Society of Agronomy-Soil Science Society of America, Madison, WI, USA, pp. 363-375.

Bolat I (2014). The effect of thinning on microbial biomass $\mathrm{C}, \mathrm{N}$ and basal respiration in black pine 
forest soils in Mudurnu, Turkey. European Journal of Forest Research 133: 131-139. - doi: 10.1007/s10342-013-0752-8

Bouyoucos GJ (1962). Hydrometer method improved for making particle size analyses of soils. Agronomy Journal 54: 464-465. - doi: 10.2134/ agronj1962.00021962005400050028x

Brady NC (1990). The nature and properties of soils (10 ${ }^{\text {th }}$ edn). Macmillan, NY, USA, pp. 621

Brookes PC, Landman A, Pruden G, Jenkinson DS (1985). Chloroform fumigation and the release of soil nitrogen: a rapid extraction metod to measure microbial biomass nitrogen in soil. Soil Biology and Biochemistry 17: 837-842. - doi: 10.1016/0038-0717(85)90144-0

Campbell CA, McConkey BG, Zentner RP, Selles F, Curtin D (1996). Long-term effects of tillage and crop rotations on soil organic $\mathrm{C}$ and total $\mathrm{N}$ in a clay soil in southwestern Saskatchewan. Canadian Journal of Soil Science 76: 395-401. doi: 10.4141/cjss96-047

Campos AC, Etchevers JB, Oleschko KL, Hidalgo CM (2012). Soil microbial biomass and nitrogen mineralization rates along an altitudinal gradient on the Cofre De Perote Volcano (Mexico): the importance of landscape position and land use. Land Degradation and Development. - doi 10.1002/ldr.2185

Cheng YB, Xia YD (2012). Soil microbial and enzymatic activities across a chronosequence of Chinese Pine plantation development on the Loess Plateau of China. Pedosphere 22 (1): 1-12. - doi: 10.1016/S1002-0160(11)60186-0

Cierjacks A, Kowarik I, Joshi J, Hempel S, Ristow M, Lippe M, Weber E (2013). Biological flora of the British Isles: Robinia pseudoacacia. Journal of Ecology 101 (6): 1623-1640. - doi: 10.1111/ 1365-2745.12162

Danso SKA, Zapata F, Awonaike KO (1995). Measurement of biological $\mathrm{N}_{2}$ fixation in fieldgrown Robinia pseudoacacia L. Soil Biology and Biochemistry 27: 415-419. - doi: 10.1016/ 0038-0717(95)98612-R

Diekow J, Mielniczuk J, Knicker H, Bayer C, Dick DP, Kögel-Knabner I (2005). Soil C and N stocks as affected by cropping systems and nitrogen fertilisation in a southern Brazil Acriso managed under no-tillage for 17 years. Soil and Tillage Research 81: 87-95. - doi: 10.1016/j.still. 2004.05.003

English NB, Weltzin JF, Fravolini A, Thomas L, Williams DG (2005). The influence of soil texture and vegetation on soil moisture under rainout shelters in a semi-desert grassland. Journal of Arid Environment 63: 324-343. - doi: 10.1016/j. jaridenv.2005.03.013

Ferreira ACC, Leite LFC, Araújo ASF, Eisenhauer N (2014). Land-use type effects on soil organic carbon and microbial properties in a semi-arid region of northeast Brazil. Land Degradation and Development (early view). - doi: 10.1002/ldr.22 82

Fterich A, Mahdhi M, Mars M (2014). The effects of Acacia tortilis subsp. raddiana, soil texture and soil depth on soil microbial and biochemical characteristics in arid zones of Tunisia. Land
Degradation and Development 25: 143-152. doi: 10.1002/ldr.1154

García-Orenes F, Guerrero C, Roldán A, MataixSolera J, Cerdà A, Campoy M, Zornoza R, Bárcenas G, Caravaca F (2010). Soil microbial biomass and activity under different agricultural management systems in a semiarid Mediterranean agroecosystem. Soil and Tillage Research 109 (2): 110-115. - doi: 10.1016/j.still.2010.05. 005

Guénon R, Vennetier M, Dupuy N, Roussos S, Pailler A, Gros R (2013). Trends in recovery of Mediterranean soil chemical properties and microbial activities after infrequent and frequent wildfires. Land Degradation and Development 24 (2): 115-128. - doi: 10.1002/ldr.1109

Haris JA (2003). Measurements of the soil microbial community for estimating the success of restoration. European Journal of Soil Science 54: 801-808. - doi: 10.1046/j.1351-0754.2003.055 9. $\mathrm{x}$

Insam H, Mitchell CC, Dormaar JF (1991). Relationship of soil microbial biomass and activity with fertilization practice and crop yield of three ultisols. Soil Biology and Biochemistry 23 (5): 459-464. - doi: 10.1016/0038-0717(91)90010-H Islam KR, Weil RR (2000). Land use effects on soil quality in a tropical forest ecosystem of Bangladesh. Agriculture, Ecosystems and Environment 79: 9-16. - doi: 10.1016/S0167-8809 (99)00145-0

Jenkinson DS, Ladd JN (1981). Microbial biomass in soil measurement and turnover. In: "Soil biochemistry, vol. 5" (Paul EA, Ladd JN eds). Marcel Dekker Inc, New York and Basel, USA, pp. 415-471.

Jenkinson DS (1988). The determination of microbial biomass carbon and nitrogen in soil. In: "Advances in nitrogen cycling in agricultural ecosystems" (Wilson JR ed). CAB, Wallingford, UK, pp. 368-386.

Johansson M-B (1995). The chemical composition of needle and leaf litter from Scots pine, Norway spruce and white birch in Scandinavian forests. Forestry 68: 49-62. - doi: 10.1093/fore stry/68.1.49

Kara O, Bolat I (2008). Soil microbial biomass C and $\mathrm{N}$ changes in relation to forest conversion in the northwestern Turkey. Land Degradation and Development 19 (4): 421-428. - doi: 10.1002/ldr. 850

Kara O, Sensoy H, Bolat I (2010). Slope length effects on microbial biomass and activity of eroded sediments. Journal of Soils and Sediments 10 (3): 434-439. - doi: 10.1007/s11368-010-0192-8 Keskin T, Makineci E (2009). Some soil properties on coal mine spoils reclaimed with black locust (Robinia pceudoacacia L.) and umbrella pine (Pinus pinea L.) in Agacli-Istanbul. Environmental Monitoring and Assessment 159 (14): 407-414. - doi: 10.1007/s10661-008-0638-2 Khan KS, Joergensen G (2006). Microbial C, N and $\mathrm{P}$ relationships in moisture stressed soils of Potohar, Pakistan. Journal of Plant Nutrition and Soil Science 169: 494-500. - doi: 10.1002/jpln. 200521904
Landgraf D, Wedig S, Klose S (2005). Mediumand short-term available organic matter, microbial biomass, and enzyme activities in soils under Pinus sylvestris L. and Robinia pseudoacacia L. in a sandy soil in NE Saxony, Germany. Journal of Plant Nutrition and Soil Science 168 (2): 193-201. - doi: 10.1002/jpln.200421384

Liao JD, Boutton TW (2008). Soil microbial biomass response to woody plant invasion of grassland. Soil Biology and Biochemistry 40: 1207-1216. - doi: 10.1016/j.soilbio.2007.12.018 Lovett GM, Weathers KC, Arthur MA (2002). Control of nitrogen loss from forested watersheds by soil carbon: nitrogen ratio and tree species composition. Ecosystems 5 (7): 712-718. - doi: 10.1007/s10021-002-0153-1

McGill WB, Cannon KR, Robertson JA, Cook FD (1986). Dynamics of soil microbial biomass and water-soluble organic $\mathrm{C}$ in Breton $\mathrm{L}$ after 50 years of cropping to two rotations. Canadian Journal of Soil Science 66: 1-19. - doi: 10.4141/ cjss86-001

Noh NJ, Son Y, Koo JW, Seo KW, Kim RH, Lee YY, Yoo KS (2010). Comparison of nitrogen fixation for north- and south-facing Robinia pseudoacacia stands in Central Korea. Journal of Plant Biology 53: 61-69. - doi: 10.1007/s12374009-9088-9

Nsabimana D, Haynes RJ, Wallis FM (2004). Size, activity and catabolic diversity of the soil microbial biomass as affected by land use. Applied Soil Ecology 26: 81-92. - doi: 10.1016/j. apsoil.2003.12.005

Oostra S, Majdi H, Olsson M (2006). Impact of tree species on soil carbon stocks and soil acidity in southern Sweden. Scandinavian Journal of Forest Research 21 (5): 364-371. - doi: 10.1080/ 02827580600950172

Pereira EL, Santos SAP, Arrobas M, Patricio MS (2011). Microbial biomass and $\mathrm{N}$ mineralization in mixed plantations of broadleaves and nitrogen-fixing species. Forest Systems 20: 516-524. - doi: 10.5424/fs/20112003-11458

Powlson DS, Brookes PC, Christensen BT (1987). Measurement of soil microbial biomass provides an early indication of changes in the total soil organic matter due to straw incorporation. Soil Biology and Biochemistry 19: 159-164. - doi: 10.1016/0038-0717(87)90076-9

Qiu L, Zhang X, Cheng J, Yin X (2010). Effects of black locust (Robinia pseudoacacia) on soil properties in the loessial gully region of the Loess Plateau, China. Plant and Soil 332: 207 217. - doi: 10.1007/s11104-010-0286-5

Rice SK, Westerman B, Federici R (2004). Impacts of the exotic, nitrogen-fixing black locust (Robinia pseudoacacia) on nitrogen-cycling in a pine-oak ecosystem. Plant Ecology 174: 97-107. - doi: 10.1023/B:VEGE.0000046049.21900.5a Rowell DL (1994). Soil science: methods and applications. Longman Publishers (Pte) Ltd, Singapore, pp. 350.

Sabo AE (2000). Robinia pseudoacacia invasions and control in North America and Europe. Restoration and Reclamation Review 6 (3): 1-9. [online] URL: http://conservancy.umn.edu/han- 
dle/11299/59729

Sparling GP (1997). Soil microbial biomass, activity and nutrient cycling as indicators of soil health. In: "Biological indicators of soil health" (Pankhurst CE, Doube BM, Gupta VVSR eds). CAB International, Wallingford, UK, pp. $97-$ 119. [online] URL: http://www.cabdirect.org/abstracts/19971907213.html

Sumner ME (1995). Sodic soils: new perspectives. In: "Australian Sodic Soils: Distribution, Properties and Management" (Naidu R, Sumner ME, Rengasamy $\mathrm{P}$ eds). CSIRO, Melbourne, Australia, pp. 1-34. - doi: 10.1071/SR9930683

Tateno R, Tokuchi N, Yamanaka N, Du S, Otsuki K, Shimamura T, Xue Z, Wang S, Hou Q (2007). Comparison of litterfall production and leaf litter decomposition between an exotic black locust plantation and an indigenous oak forest near Yan'an on the Loess Plateau, China. Forest Ecology and Management 241: 84-90. - doi: 10.1016 /j.foreco.2006.12.026

Thornthwaite CW (1948). An approach toward a rational classification of climate. The Geographical Review 38: 55-94. - doi: 10.2307/210739 TSMS (2013). Daily meteorological data. The Turkish State Meteorological Service, Ankara, Turkey, web site. [online] http://www.mgm.gov$\operatorname{tr} /$

Ussiri DAN, Lal R, Jacinthe PA (2006). Soil properties and carbon sequestration of afforested pastures in reclaimed minesoils of Ohio. Soil Science Society of America Journal 70: 17971806. - doi: 10.2136/sssaj2005.0352

Vance ED, Brookes PC, Jenkinson DS (1987). An extraction method for measuring soil microbial biomass C. Soil Biology and Biochemistry 19: 703-707. - doi: 10.1016/0038-0717(87)90052-6 Vitousek PM, Walker LR (1989). Biological invasion by Myrica faya in Hawaii: plant demography, nitrogen fixation and ecosystem effects. Ecological Monographs 59: 247-265. - doi: 10.2307/1942601

Wang B, Liu G, Xue S (2012). Effect of black locust (Robinia pseudoacacia) on soil chemical and microbiological properties in the eroded hilly area of China's Loess Plateau. Environmental Earth Sciences 65 (3): 597-607. - doi: 10.100 7/s12665-011-1107-8

Wardle DA (1992). A comparative assessment of factors which influence microbial biomass carbon and nitrogen levels in soil. Biology Reviews 67: 321-358. - doi: 10.1111/j.1469-185X.1992. tb00728.x

Wardle DA (1993). Changes in the microbial biomass and metabolic quotient during leaf litter succession in some New Zealand forest and scrubland ecosystems. Functional Ecology 7: 346-355. - doi: 10.2307/2390215

Winding A, Hund-Rinke K, Rutgers M (2005). The use of microorganisms in ecological soil classification and assessment concepts. Ecotoxicology and Environmental Safety 62: 230-248. doi: 10.1016/j.ecoenv.2005.03.026

Xue S, Liu G, Dai Q, Wei W, Hou X (2007). Evolution of soil microbial biomass in the restoration process of artificial Robinia pseudoacacia under erosion environment. Acta Ecologica Sinica 27: 909-917.

Yüksek T (2012). The restoration effects of black locust (Robinia pseudoacacia L) plantation on surface soil properties and carbon sequestration on lower hillslopes in the semi-humid region of Coruh Drainage Basin in Turkey. Catena 90: 1825. - doi: 10.1016/j.catena.2011.10.001

Zeller B, Colin-Belgrand M, Dambrine E, Martin F, Bottner P (2000). Decomposition of ${ }^{15} \mathrm{~N}-\mathrm{la}-$ belled beech litter and fate of nitrogen derived from litter in a beech forest. Oecologia 123: 550559. - doi: 10.1007/PL00008860

Zhao Z, Shahrour I, Bai Z, Fan W, Feng L, Li H (2013). Soils development in opencast coal mine spoils reclaimed for 1-13 years in the WestNorthern Loess Plateau of China. European Journal of Soil Biology 55: 40-46. - doi: 10.1016/j.ejsobi.2012.08.006

Zhou ZC, Shangguan ZP (2005). Soil anti-scouribility enhanced by plant roots. Journal of Integrative Plant Biology 47: 676-682. - doi: 10.1111/j.1744-7909.2005.00067.x 